much damage. The species concerned is a common one which often causes local and temporary injury to grass. Its appearance in epidemic form on cereals is quite unique in recent times. The reasons for the outbreak are unknown, but they are probably associated with the relatively mild autumn and winter and the advanced condition of the crops. The standard control method would be the application of an insecticidal dust by means of a powder sprayer. The necessary equipment, however, is not available on many farms, and expenditure to meet this treatment seems scarcely justifiable in view of the damage that has already been done. It is probable that the aphids will shortly migrate, while natural enemies are already actively at work.

\section{Metals in Food}

THE Society of Public Analysts has issued a useful "Bibliography of the More Important Heavy Metals occurring in Food and Biological Material", the period covered being the years 1921-33. The elements dealt with are antimony, bismuth, cadmium, chromium, cobalt, copper, lead, manganese, mercury, nickel, thallium, tin and zinc. Each reference indicates the nature of the information to be found in the paper. The largest sections deal with copper, lead and manganese, which account for half the references quoted. The pamphlet (30 pages) can be obtained from the Editor of the Analyst, 85 Eccleston Square, London, S.W.1 (2s. to members of the Society; $3 s$. to non-members).

\section{Principles and Design of Precision Gauges}

IN these days of motor-cars, electric fittings and so on, everyone learns something of the value of interchangeability of parts and also experiences the disadvantage of finding that a part 'will not fit'. The progress of manufacture, indeed, depends largely on parts being interchangeable, and in mass production it is absolutely necessary to place limits on the permissible variation from standard dimensions. This necessity has given rise to the system of working to gauges, a system which received a great impetus through the manufacture of vast quantities of munitions during the War, and which to-day is perhaps used most extensively in the manufacture of motor-car engines and other parts. From being a comparative novelty, gauging has become a matter of ordinary routine, while the making and testing of gauges has itself become an industry. There will thus be many persons who will be able to appreciate the pamphlet of Mr. R. J. Foster on "The Principle and Design of Precision Gauges for Interchangeability" recently issued by the Association of Engineering and Ship-building Draughtsmen, and published by the Draughtsman Publishing Co., Ltd. (2s.). In this the reader will find sections on tolerances and fits and limits, plug gauges, pin gauges, external and internal gauges, height and depth gauges and comparators, together with many sketches and useful notes.

\section{International Geological Congress}

Premiminary arrangements are announced from Moscow for the meetings of the Seventeenth International Geological Cingress. which is to be held in the U.S.S.R. during the summer of 1937, the year of the twentieth anniversary of the Soviet Government. It is proposed that the first half of August should be devoted to the sessional meetings. The special topics suggested for discussion include petroleum, coal, ore-deposits, rare elements, geophysical methods, the Permian system, tectonic and geochemical problems, the relationship of magmatic rocks and ore-deposits to tectonics, and the history of geological knowledge. Three series of excursions, $A, B$ and $C$, are provisionally arranged, to take place respectively before, during and after the sessions, the whole programme extending from the beginning of July to the end of September. The $A$ series includes excursions to the north (Pre-Cambrian and Khibina Complex); the Urals ; the south (Crimea and Donets Basin); the Volga Basin ; and the Caucasus. The $C$ series are on a larger scale and cover very wide regions. They are described as petroleum and stratigraphical (main oil districts and Central Asia); Central Asia (stratigraphy, tectonics and volcanic phenomena; transcontinental (stratigraphy, tectonics and economic geology of Urals to Soviet Far East); and Turkestan-Siberia (Perm, Altai and Kuznetsk). More detailed descriptions will be given later. Meanwhile inquiries are invited and should be addressed to the Organisation Committee of the Seventeenth International Geological Congress, Moscow, 4, KoteInicheskaya, Naberezhnaya, 17.

\section{A Recent Sunspot}

A FAIRLy large group of sunspots has recently been visible whilst crossing the sun's disc on June 23-July 6 in long. $305^{\circ}$ and lat. $24^{\circ} \mathrm{S}$. Its area on June 28 was 1000 millionths of the sun's hemisphere, of which 850 millionths was the area of the leader spot. When near central meridian passage, which occurred on June $29 \cdot 9$, the group was visible to the naked eye. Though itself not a return of an individual spot of the previous rotation, the recent spot represented a continuation of localised disturbance which has been apparent for the last two months in this part of the solar surface. In an ordinary telescope, the group has been an interesting object with conspicuous 'bridges' across the leader spot in particular. The spectroscope offered, as usual, a further range of observation. On June 26 at $8^{\mathrm{h}} 45^{\mathrm{m}}$ G.M.T. a bright eruption took place that was observable visually in the hydrogen $C$ line of the solar spectrum and should have been possible to photographic records in the $H$ and $K$ lines of ionised calcium. The spectrohelioscope showed with perfection the contour of the areas of the brilliant hydrogen $(\mathrm{H} \alpha)$ emission and the dark filaments of gas bordering them at a later stage. The largest radial velocities measured at Greenwich for the absorption filaments were $20 \mathrm{~km}$. a sec. outwards and $60 \mathrm{~km}$. a sec. inwards to the sun. On June 29 at about $8^{\mathrm{h}} 45^{\mathrm{m}}$, several moderately large radial

(Continued on p. 27.) 
velocities were recorded for about $\frac{1}{4}$ hour. The minimum of the preceding 11-year cycle having occurred at $1933 \cdot 8$, the present spot with respect to size is not unusual, but it is the largest one seen for more than a year, and its appearance is one of several indications that the new cycle is now well-established.

\section{Announcements}

Dr. Richard Anschütz, professor of chemistry in the University of Bonn, has been elected a foreign honorary fellow of the Royal Society of Edinburgh.

IT was announced at the general monthly meeting of members of the Royal Institution on July 1 that the Managers had elected Dr. Edward Mellanby to be Fullerian professor of physiology in the Institution, in succession to Sir Grafton Elliot Smith. The appointment is for a term of three years, in accordance with the provisions of the deed of trust of the professorship. Dr. Mellanby is the secretary of the Medical Research Council, and emeritus professor of pharmacology in the University of Sheffield. It is expected that he will give his first course of lectures at the Royal Institution in the autumn.

DR. R. F. LAWRENCE, who has been assistant in charge of reptiles, amphibians, and arachnids at the South African Museum since 1922, has been appointed director of the Natal Museum, Pietermaritzburg, as from July 1.

Dr. Harvey Cushing, of New Haven, Conn., has been recently awarded the Gold Medal of the National Institute of Social Science in recognition of "distinguished services rendered to humanity". Dr. Cushing received the Lister Medal of the Royal College of Surgeons in 1930, and is the author of the life of Sir William Osler which won the Politzer prize for biography in 1925.

THF Hungarian Academy of Science has elected as honorary member Baron A. Koranyi, professor of internal medicine at Budapest.

THE annual conference of the Association for Combating and Preventing Corrosion, under the auspices of the Society of German Chemists (Verein deutscher Chemiker e.V., Berlin W 35, Potsdamer Str. 103a), will be held in Berlin on November 18-19, 1935. The subject for discussion is "Corrosion by Water".

THE President of the Republic of Peru has appointed a committee composed of the director of public health, the president of the National Academy of Medicine and Prof. Constantino Carvallo, as representatives of the medical faculty to elaborate a plan for the establishment of a serological institute which, in addition to producing serums and vaccines, will undertake researches in chemistry, bacteriology and biochemistry.

AN Electrodeposition Exhibition will be held in the Science Museum, South Kensington, from July 25 until October. The purpose of the exhibition is to illustrate all phases of electrodeposition and the underlying scientific principles. It has been organised by the Electrodepositors' Technical Society, Northampton Polytechnic Institute, London, E.C.1, from which further information can be obtained.

Tre friends, colleagues and pupils of the late Prof. Léon Bernard, formerly president of the Health Section of the League of Nations and physician to the Hôpital Laennec, Paris, desire to honour his memory by placing a medallion of him in his hospital, and founding an international prize for social medicine. A reproduction of the medallion will be given to each subscriber. Subscriptions should be sent to the treasurer, M. Georges Masson, 120 Boulevard St. Germain, Paris, $6^{\mathrm{e}}$.

A PARTy of Moseow men of science is about to explore the Kara Kum desert in Central Asia. The expedition will be absent for four months, and will investigate the natural resources of areas in the northern and south-eastern parts of the desert.

UNDER the title "Iodine for Livestock", a pamphlet has been issued free of charge by the Nitrate Corporation of Chile, Stone House, Bishopsgate, E.C.2. The pamphlet, which has been compiled by Mr. Frank Corrie, contains several excellent illustrations, and deals at length with the relation between iodine and the various problems of animal health and nutrition, and practical advice is given on the use of iodine in feeding stock.

Applications are invited for the following appointments, on or before the dates mentioned :

A lecturer in engineering in the Plymouth and Devonport Technical College-The Secretary for Education, Cobourg Street, Plymouth (July 10).

A lecturer in production engineering in the Dudley and Staffordshire Technical College-The Clerk to the Governors, Education Offices, St. James's Road, Dudley (July 10).

A lecturer and a student demonstrator in botany in University College, Exeter-The Registrar (July 12).

A chief Government mining engineer in the Department of Mines, Southern Rhodesia-The Official Secretary, Office of the High Commissioner for Southern Rhodesia, Crown House, Aldwych, London, W.C.2 (July 15).

An assistant professor of mathematics in the Royal Naval College, Greenwich-The Adviser on Education, Admiralty, Whitehall, S.W.1 (July 15).

An assistant demonstrator in physics in the Royal Holloway College, Englefield Green, Surrey-The Principal (July 17).

A lecturer in mathematics in the Bingley Training College-The Education Officer, County Hall, Wakefield, Yorkshire (July 24).

An assistant lecturer in civil engineering in Battersea Polytechnic, London, S.W.11-The Principal.

A lecturer in botany, zoology and microbiology in the College of Technology, Leeds-The Director of Education, Education Department, Calverley Street, Leeds, 1. 